\title{
Analisis Image Likes to Followers Ratio Instagram Pada 5 Brand Sepatu Lokal Terbaik di Tahun 2021
}

\author{
I Putu Agus Arya Wibawa \\ STMIK STIKOM Indonesia \\ agusaryaw14@gmail.com
}

\begin{abstract}
Instagram is an image-based social media that provides online photo or video sharing services. In the Instagram app, it allows users to upload photos and videos into a feed which can be edited with various filters and organized with tags and location information. In Indonesia, the number of Instagram users until July 2021 is 91.77 million users, making Indonesia the country with the fourth most Instagram users in the world. The largest users are in the 18-24 year age group, which is $36.4 \%$. The large number of Instagram users in Indonesia can certainly provide opportunities for many brands to make Instagram social media a social media marketing platform. There are 5 local shoe brands in Indonesia that use Instagram as a marketing platform, namely: Aero Street, Ventela Shoes, Sepatu Compass, Sage Footwear, and Piero Indonesia. The purpose of this study is to calculate the credibility of the Instagram account performance of the 5 Best Local Shoe Brands in 2021. The method used for this research is a quantitative exploratory method. The results of this study indicate that the Sepatu Compass brand is ranked first and has good account performance credibility.
\end{abstract}

\begin{abstract}
ABSTRAK
Instagram adalah sosial media berbasis gambar yang memberikan layanan berbagi foto atau video secara online. Pada aplikasi Instagram, memungkinkan pengguna untuk mengunggah foto dan video ke dalam feed yang dapat diedit dengan berbagai filter dan diatur dengan tag dan informasi lokasi. Di Indonesia, jumlah pengguna Instagram hingga Juli 2021 sebesar 91,77 juta pengguna sehingga menjadikan Indonesia sebagai negara dengan pengguna Instagram terbanyak ke empat di Dunia. Pengguna terbesar terdapat di kelompok usia 18 - 24 tahun yaitu $36,4 \%$. Banyaknya pengguna Instagram di Indonesia tentu dapat memberikan peluang bagi banyak brand untuk menjadikan media sosial Instagram sebagai platform media sosial marketing. Adapun 5 brand sepatu lokal di Indonesia yang memanfaatkan Instagram sebagai platform marketing, yaitu : Aero Street, Ventela Shoes, Sepatu Compass, Sage Footwear, dan Piero Indonesia. Tujuan dari penelitian ini yaitu untuk menghitung kredibilitas dari performa akun Instagram 5 Brand Sepatu Lokal Terbaik di Tahun 2021. Metode yang digunakan untuk
\end{abstract}


penelitian ini yaitu metode eksploratif kuantitatif. Hasil dari penelitian ini menunjukan bahwa brand Sepatu Compass mendapatkan peringkat pertama dan memiliki kredibilitas performa akun yang baik.

Keyword : Credibility Account Instagram ; Social Media Marketing ; Social Media Instagram ;Image Likes to Followers Ratio ; Brand Sepatu Lokal di Indonesia.

\section{PENDAHULUAN}

Pada ara modern Revolusi Industri 4.0 sekarang ini, hampir seluruh aktivitas kehidupan manusia sudah tidak bisa terlepas dari penggunaan teknologi informasi sebagai Enabler bagi kegiatan dan layanan lainnya. Penggunaan Teknologi Informasi tidak lagi hanya sebagai alat bantu saja tetapi merupakan komponen wajib yang harus dimiliki. Adanya perkembangan Teknologi Informasi yang sangat memudahkan aktivitas kehidupan manusia sudah menyebabkan ketergantungan yang sangat tinggi akan keberadaan teknoologi informasi. Teknologi Informasi ini adalah suatu teknologi yang digunakan untuk mengelolah data dan informasi, termasuk memproses, mendapatkan, menyusun dan menyimpan serta memanipulasi data dengan berbagai cara untuk menghasilkan informasi yang berkualitas, yaitu informasi yang relevan, akurat dan tepat waktu, yang digunakan untuk keperluan pribadi, bisnis, dan pemerintahan

Media sosial saat ini telah menjadi trend dalam komunikasi pemasaran. Media sosial adalah sebuah media online, dengan para penggunanya bisa dengan mudah berpartisipasi, berbagi, dan menciptakan isi meliputi blog, jejaring sosial, wiki, forum dan dunia virtual. Blog, jejaring sosial, dan wiki merupakan bentuk media sosial yang paling umum digunakan oleh masyarakat di seluruh dunia. Media sosial sebagai "sebuah kelompok aplikasi berbasis internet yang membangun di atas dasar ideologi dan teknologi Web 2.0, dan yang memungkinkan penciptaan dan pertukaran user-generated content" (Kaplan \& Haenlein, 2010). Beberapa contoh media sosial yang sedang berkembang saat ini yaitu Instragam, Twitter, Line, Facebook, Youtube, dan lain-lain.

Media sosial Instagram adalah sosial media berbasis gambar yang memberikan layanan berbagi foto atau video secara online. Instagram berasal dari pengertian dari keseluruhan fungsi aplikasi ini. Kata "insta" berasal dari kata "instan", seperti kamera polaroid yang pada masanya lebih dikenal dengan sebutan "foto instan". Instagram juga dapat menampilkan foto-foto secara instan, seperti polaroid di dalam tampilannya. Sedangkan untuk kata "gram" berasal dari kata "telegram" yang cara kerjanya untuk mengirimkan informasi kepada orang lain dengan cepat. Sama halnya dengan Instagram yang dapat mengunggah foto dengan menggunakan jaringan Internet, sehingga informasi yang ingin disampaikan dapat diterima dengan cepat. Oleh karena itulah Instagram merupakan kata yang dari kata instan dan telegram.

Pada aplikasi Instagram, memungkinkan pengguna untuk mengunggah foto dan video ke dalam feed yang dapat diedit dengan berbagai filter dan diatur dengan tag dan informasi lokasi. Unggahan dapat dibagikan secara publik atau dengan pengikut yang disetujui sebelumnya. Pengguna dapat menjelajahi konten pengguna lain berdasarkan tag dan lokasi dan melihat konten yang sedang tren. Pengguna dapat menyukai foto serta mengikuti pengguna lain untuk 
menambahkan konten mereka masuk kepada beranda. Dengan adanya media sosial Instagram, banyak menarik brand - brand produk untuk mempromosikan produknya melalui media sosial seperti contohnya yaitu brand sepatu lokal asli Indonesia. Adapun 5 Brand Sepatu Lokal di Indonesia, diantaranya yaitu : Aero Street, Ventela Shoes, Sepatu Compass, Sage Footwear, dan Piero Indonesia (5 Brand Sepatu Lokal Terbaik Di Tahun 2021, n.d.).

Penelitian ini menggunakan metode eksploratif kuantitatif, dan akan menghitung menggunakan rasio-rasio yang ada pada Instagram. Terdapat 14 rasio yang ada pada sosial media Instagram dan relevan digunakan sebagai media ukur kredibilitas akun yang ada. Penelitian ini hanya berfokus untuk menghitung kredibilitas Image Likes to Followers Ratio Instagram pada 5 Brand Sepatu Lokal di Tahun 2021. Adapun Top 5 Brand Sepatu Lokal di Indonesia, diantaranya yaitu : Aero Street, Ventela Shoes, Sepatu Compass, Sage Footwear, dan Piero Indonesia (5 Brand Sepatu Lokal Terbaik Di Tahun 2021, n.d.). Tujuan dari penelitian ini adalah mengetahui kredibilitas performa dari akun Instagram 5 Brand Sepatu Lokal di Indonesia menggunakan Image Likes to Followers Ratio.

\section{TINJAUAN PUSTAKA}

Media sosial adalah salah satu dampak yang muncul akibat semakin berkembangnya dunia baru saat ini. Media sosial merupakan media internet yang memungkinkan pengguna dapat mempresentasikan dirinya maupun berinteraksi, bekerja sama, berbagi, berkomunikasi dengan dunia lain dan membentuk ikatan sosial secara virtual (Nasrullah, 2016). Jadi manusia dapat saling terkoneksi di intenet dan membuat sebuah komunitas sosial di dunia maya dan menciptakan medianya untuk lebih memudahkan lagi dalam berinteraksi satu sama lain.

Berkembangnya media sosial ini tentunya berbanding lurus dengan berkembangnya teknologi komunikasi. Era smartphone menjadi tonggak majunya media sosial. Hal ini dikarenakan semenjak kemunculannya, mulai banyak media sosial yang bermunculan sehingga mempermudah proses komunikasi.

Instagram merupakan salah satu bentuk hasil dari kemajuan internet dan tergolong salah satu media sosial yang cukup digandrungi oleh khalayak masa kini. Hal ini dapat dibuktikan dengan meningkatnya pengguna instagram pada setiap tahunnya. Terhitung pada April 2017 lalu, Instagram mengumumkan bahwa pengguna aktiv bulanannya telah mencapai kisaran 800 juta akun dan angka tersebut lebih banyak dibandingkan tahun sebelumnya (Yusuf, 2017).

Berbeda dengan media sosial lainnya, instagram menitik beratkan kepada postingan foto dan video dari para penggunanya. Keunikan yang membuat instagram satu ini berbeda dengan media sosial pada umumnya. Apalagi, instagram seringkali memperbaharui sistemnya. Sejak kemunculannya pada tahun 2010 silam, instagram sering memperbarui fitur yang ada sehingga fiturnya lebih lengkap dan lebih menarik.

Selain itu, instagram juga merupakan salah satu pendorong berkembangnya di bidang industri pemasaran. Ada banyak wirausaha yang memanfaatkan instagram ini sebagai media promosi untuk barang ataupun jasa yang ditawarkan. Tak hanya pengusaha kecil, ada banyak brand 16 
internasional juga memanfaatkan instagram secara intens untuk memberikan informasi tentang barang yang mereka produksi.

\section{METODE PENELITIAN}

Penelitian ini menggunakan metode eksploratif kuantitatif untuk mengetahui kredibilitas dari performa akun Instagram 5 Brand Sepatu Lokal Terbaik di Tahun 2021. Metode eksploratif merupakan penelitian yang memiliki tujuan untuk melakukan eksplorasi atau memperdalam pengetahuan ataupun ide-ide baru mengenai suatu hal yang baru, guna merumuskan permasalahan secara terperinci (Maryam, Isrok'atun, and Aeni 2016).

Tujuan dari penelitian ini yaitu mengetahui nilai kredibillitas dari performa akun Instagram 5 Brand Sepatu Lokal Terbaik di Tahun 2021. Ada beberapa langkah yang sangat penting dan harus dilaksanakan dalam penelitian ini, sehingga mampu menemukan peringkat pertama untuk akun Instagram 5 Brand Sepatu Lokal yang memiliki performa terbaik di tahun 2021. Berikut langkah-langkah yang dilakukan pada penelitian ini, yaitu :

1. Melakukan Eksplorasi Pada Website Untuk Menentukan Objek yang Akan Dijadikan Topik Analisa.

Eksplorasi ini dilakukan dalam beberapa website yang menyediakan keterangan tentang objek yang akan di teliti. Setelah ekslorasi terselesaikan, sebagai akibatnya ditemukan nama-nama brand sepatu lokal yang akan dijadikan objek analisa. Setelah melakukan eksplorasi dalam halaman website, maka langkah selanjutnya yaitu mencari nama akun Instagram dari masing-masing brand sepatu lokal. Pastikan seluruh brand mempunyai akun pada aplikasi sosial media Instagram.

2. Menghitung Nilai Rata - Rata Variabel Dari 5 Brand Sepatu Lokal Terbaik di Tahun 2021.

Pada langkah ini, peneliti menghitung nilai variable image likes dan variable followers. Variabel adalah sesuatu yang mempunyai nilai bervariasi dimana nilai tersebut bisa dijadikan sebagai dasar untuk empat data yang tidak sama seperti rasio, skala, ordinal, nominal dan internal (Rankuti 2015). Untuk menghitung nilai rata-rata dari variabel image likes dan variable followers yaitu dengan cara mengambil minimal 10 postingan lalu di hitung sehingga menemukan nilai rata-rata dari masing-masing variabel. 


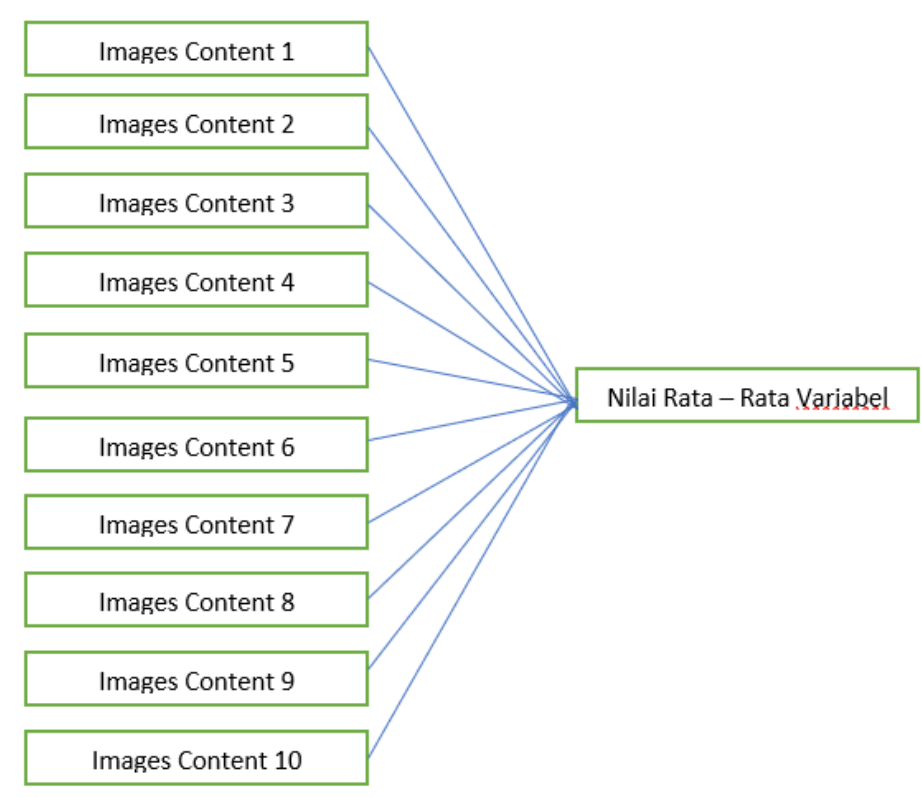

Gambar 1. Analisa Nilai Rata - Rata Variabel

\section{Menghitung Nilai Kredibilitas Akun}

Untuk menghitung nilai kredibilitas dari image likes to followers ratio, peneliti menggunakan cara membagi nilai variabel pertama dengan nilai variabel kedua. Jika image likes memiliki nilai 15 dan followers memiliki nilai 35, maka cara menghitungnya yaitu $15: 35=0,428$. Dengan begitu nilai dari image likes to followers ratio adalah 0,428 .

\section{Menentukan Peringkat Pada Akun Instagram \}

Pada langkah terakhir yang dilakukan dalam penelitian ini yaitu menentukan peringkat pada masing-masing rasio yang ada. Pada penentuan peringkat perlu melihat karakteristik berdasarkan rasio yang di teliti. apabila karakteristik rasio adalah rendah, maka objek yang mempunyai nilai terendah akan mendapatkan angka 5 dan objek yang mempunyai nilai tertinggi akan mendapatkan angka 1. Tetapi apabila rasio memiliki karakteritik tinggi maka objek yang mendapatkan nilai tinggi akan mendapatkan angka 5 dan objek yang mendapatkan nilai terendah akan mendapatkan angka 1. Setelah mendapatkan hasil kredibilitas ratio maka dapat disimpulkan objek yang mana mendapatkan peringkat 1 sampai dengan peringkat 5 . 


\section{HASIL DAN PEMBAHASAN}

Akun Instagram dari 5 Brand Sepatu Lokal Terbaik di Tahun 2021, diantaranya:

\section{Aero Street}

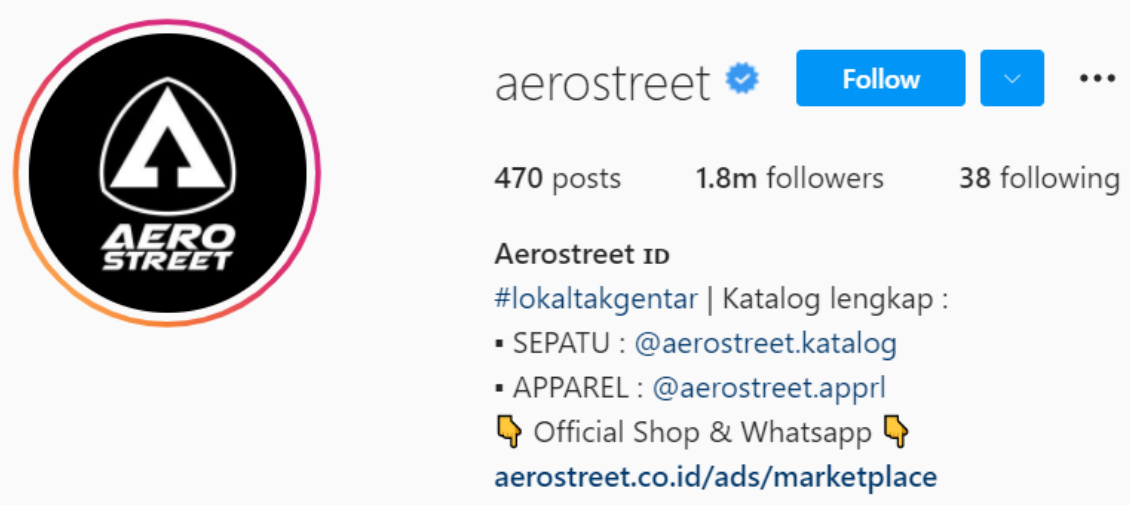

Gambar 1. Akun Instagram Aero Street

Sumber : https://www.instagram.com/aerostreet/ (akses pada 21-10-2021)

\section{Ventela Shoes}

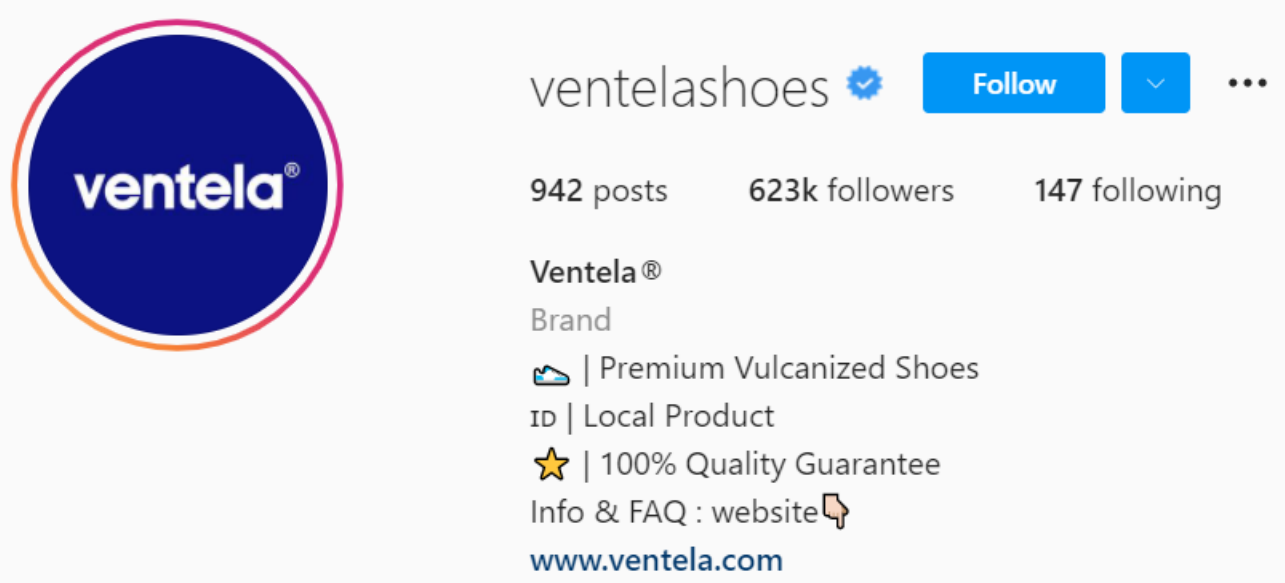

Gambar 2. Akun Instagram Ventela Shoes

Sumber : https://www.instagram.com/ventelashoes/ (akses pada 21-10-2021) 


\section{Sepatu Compas}
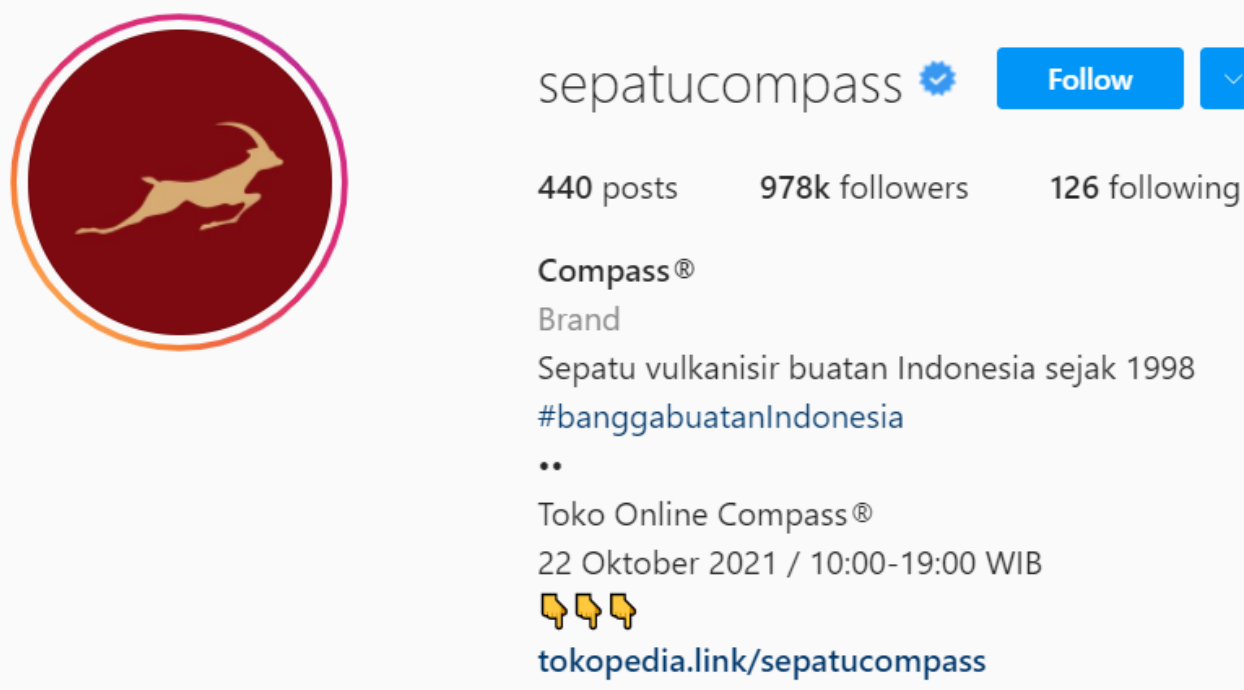

Gambar 3. Akun Instagram Sepatu Compass

Sumber : https://www.instagram.com/sepatucompass/ (akses pada 21-10-2021)

\section{Sage Footwear}

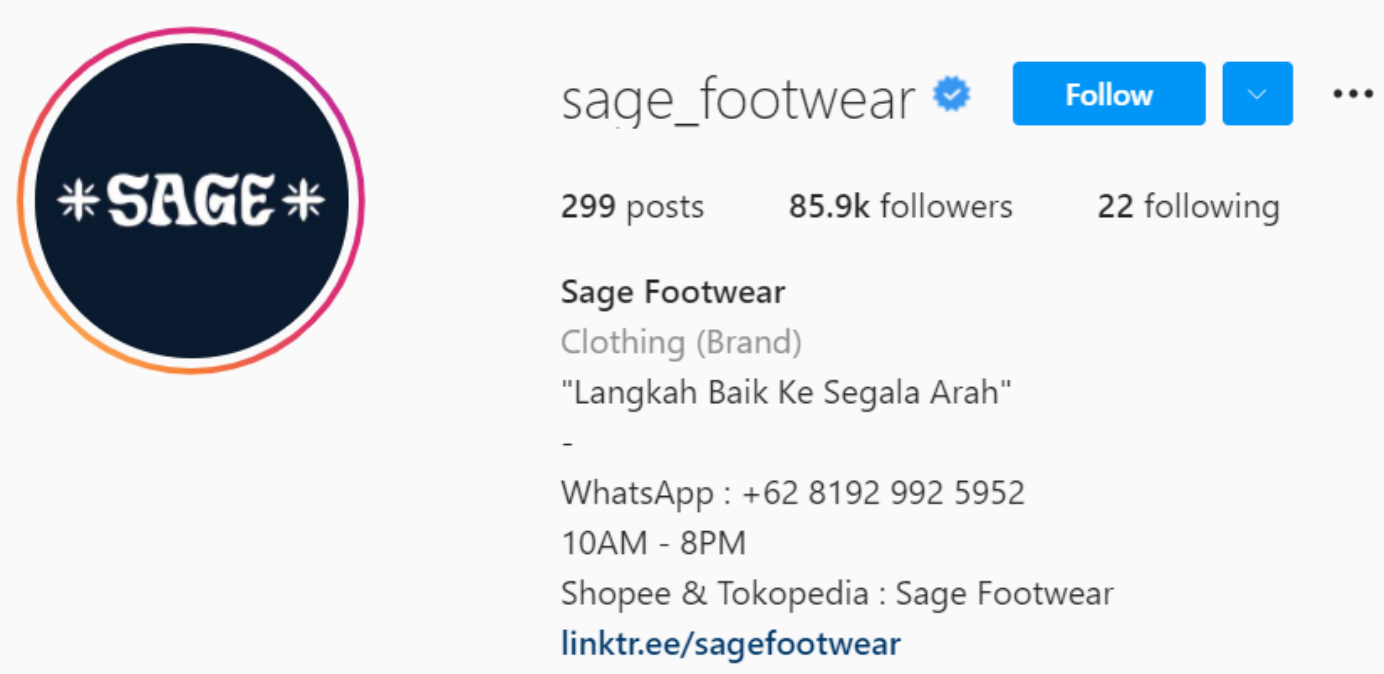

Gambar 4. Akun Instagram Sage Footwear

Sumber : https://www.instagram.com/sage_footwear/ (akses pada 21-10-2021) 


\section{Piero Indonesia}

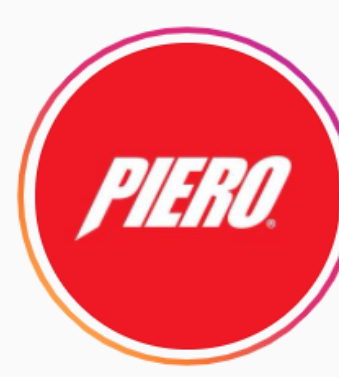

pieroindonesia

Follow

905 posts $\quad 191 \mathrm{k}$ followers

Piero Indonesia

Product/service

Official account of Piero Indonesia

Tag us with \#pieroindonesia

linktr.ee/PIERO.INDONESIA

Followed by aldinonh

Gambar 1. Akun Instagram Piero indonesia

Sumber : https://www.instagram.com/pieroindonesia/ (akses pada 21-10-2021)

Dari kelima Brand Sepatu Lokal Terbaik di Tahun 2021, peneliti menemukan nilai dari masingmasing variabel yang ada untuk menghitung rasio Image Likes to Followers Rasio dari setiap akun. Pada akun Instagram terdapat 8 variabel, diantaranya yaitu :

1. Posts

2. Followers

3. Following

4. Video Likes

5. Video Comments

6. Video Views

7. Image Likes

8. Image Comments

Dari kedelapan variabel tersebut peneliti hanya fokus untuk menemukan hasil dari 2 variabel, yaitu:

1. Image Likes

2. Followers

Dari kedua variabel tersebut kemudian dianalisa sehingga menemukan nilai rata-rata dari variabel image likes dan jumlah followers. Untuk menghitung nilai rata-rata dari variabel image likes dan followers yaitu dengan cara mengambil minimal 10 postingan kemudian dibagi dengan jumlah followers sehingga menemukan nilai rata-rata dari total video likes dan followers. Berikut merupakan tabel nilai rata-rata dari masing-masing brand sepatu local terbaik di tahun 2021, yaitu: 
Tabel 1. Analisa Nilai Rata-Rata Variabel Image Likes Akun Instagram Aero Street

\begin{tabular}{|c|c|}
\hline \multicolumn{2}{|c|}{ Aero Street } \\
\hline No & $\begin{array}{c}\text { Image } \\
\text { Likes }\end{array}$ \\
\hline 1 & 16.718 \\
\hline 2 & 41.434 \\
\hline 3 & 23.096 \\
\hline 4 & 62.980 \\
\hline 5 & 21.613 \\
\hline 6 & 47.083 \\
\hline 7 & 22.722 \\
\hline 8 & 13.636 \\
\hline 9 & 33.476 \\
\hline 10 & 48.535 \\
\hline Total & $\mathbf{3 3 . 1 2 9}$ \\
\hline
\end{tabular}

Sumber : Pengolah Data Excel

Tabel 2. Analisa Nilai Rata-Rata Variabel Image Likes Akun Instagram Ventela Shoes

\begin{tabular}{|c|r|}
\hline \multicolumn{2}{|c|}{ Ventela Shoes } \\
\hline No & Image Likes \\
\hline 1 & 42.147 \\
\hline 2 & 21.830 \\
\hline 3 & 7.197 \\
\hline 4 & 11.796 \\
\hline 5 & 6.403 \\
\hline 6 & 9.542 \\
\hline 7 & 10.997 \\
\hline 8 & 10.165 \\
\hline 9 & 13.527 \\
\hline 10 & 7.770 \\
\hline Total & $\mathbf{1 4 . 1 3 7}$ \\
\hline
\end{tabular}

Sumber : Pengolah Data Excel

Tabel 3. Analisa Nilai Rata-Rata Variabel Image Likes Akun Instagram Sepatu Compass

\begin{tabular}{|c|r|}
\hline \multicolumn{2}{|c|}{ Sepatu Compass } \\
\hline No & Image Likes \\
\hline 1 & 45.519 \\
\hline 2 & 19.831 \\
\hline 3 & 22.886 \\
\hline 4 & 26.157 \\
\hline 5 & 15.615 \\
\hline 6 & 29.664 \\
\hline 7 & 42.063 \\
\hline
\end{tabular}




\begin{tabular}{|c|r|}
\hline 8 & 35.647 \\
\hline 9 & 64.023 \\
\hline 10 & 40.252 \\
\hline Total & $\mathbf{3 4 . 1 6 6}$ \\
\hline
\end{tabular}

Sumber : Pengolah Data Excel

Tabel 4. Analisa Nilai Rata-Rata Variabel Image Likes Akun Instagram Sage Footwear

\begin{tabular}{|c|r|}
\hline \multicolumn{2}{|c|}{ Sage Footwear } \\
\hline No & Image Likes \\
\hline 1 & 196 \\
\hline 2 & 249 \\
\hline 3 & 932 \\
\hline 4 & 300 \\
\hline 5 & 300 \\
\hline 6 & 213 \\
\hline 7 & 579 \\
\hline 8 & 724 \\
\hline 9 & 1.367 \\
\hline 10 & 576 \\
\hline Total & $\mathbf{5 4 4}$ \\
\hline
\end{tabular}

Sumber : Pengolah Data Excel

Tabel 5. Analisa Nilai Rata-Rata Variabel Image Likes Akun Instagram Piero Indonesia

\begin{tabular}{|c|r|}
\hline \multicolumn{2}{|c|}{ Piero Indonesia } \\
\hline No & Image Likes \\
\hline 1 & 1.058 \\
\hline 2 & 1.208 \\
\hline 3 & 1.376 \\
\hline 4 & 428 \\
\hline 5 & 671 \\
\hline 6 & 1.469 \\
\hline 7 & 1.192 \\
\hline 8 & 1.087 \\
\hline 9 & 2.021 \\
\hline 10 & 1.499 \\
\hline Total & $\mathbf{1 . 2 0 1}$ \\
\hline
\end{tabular}

Sumber : Pengolah Data Excel 
Tabel 6. Nilai Variabel Pada Akun Instagram 5 Brand Sepatu Lokal Terbaik di Tahun 2021

\begin{tabular}{|l|r|r|r|r|r|}
\hline \multicolumn{1}{|c|}{ Variable } & \multicolumn{1}{c|}{$\begin{array}{c}\text { Aero } \\
\text { Street }\end{array}$} & \multicolumn{1}{c|}{$\begin{array}{c}\text { Ventela } \\
\text { Shoes }\end{array}$} & \multicolumn{1}{c|}{$\begin{array}{c}\text { Sepatu } \\
\text { Compass }\end{array}$} & \multicolumn{1}{c|}{$\begin{array}{c}\text { Sage } \\
\text { Footwear }\end{array}$} & \multicolumn{1}{c|}{$\begin{array}{c}\text { Piero } \\
\text { Indonesia }\end{array}$} \\
\hline Image & 33.129 & 14.137 & 34.166 & 544 & 1.201 \\
\hline Followers & 1.800 .000 & 623.000 & 978.000 & 85.900 & 191.000 \\
\hline \multicolumn{7}{r}{ Sumber : Pengolah Data Excel }
\end{tabular}

Pada akun Instagram terdapat 8 rasio yang relevan digunakan untuk mengukur kredibilitas pada masing-masing akun. Namun pada penelitian kali ini hanya berfokus untuk menghitung Image Likes to Followers Ratio. Untuk menghitung kredibilitas dari masing-masing akun Instagram setiap brand sepatu, peneliti menghitung dengan cara : variabel 1 akan dibagi dengan variabel 2, sehingga ditemukan hasil analisisa dari rasio tersebut.

Tabel 7. Hasil Perhitungan Rasio Akun Instagram

\begin{tabular}{|c|c|c|c|c|c|c|}
\hline $\begin{array}{c}\text { N } \\
\text { o }\end{array}$ & \multicolumn{1}{|c|}{ RATIO } & $\begin{array}{c}\text { Aero } \\
\text { Street }\end{array}$ & $\begin{array}{c}\text { Ventela } \\
\text { Shoes }\end{array}$ & $\begin{array}{c}\text { Sepatu } \\
\text { Compass }\end{array}$ & $\begin{array}{c}\text { Sage } \\
\text { Footwear }\end{array}$ & $\begin{array}{c}\text { Piero } \\
\text { Indonesia }\end{array}$ \\
\hline \multirow{2}{*}{1} & $\begin{array}{l}\text { Image Likes to } \\
\text { Followers Ratio }\end{array}$ & 0,01840500 & 0,02269181 & 0,03493456 & 0,00633295 & 0,00628796 \\
\hline
\end{tabular}

Sumber : Pengolah Data Excel

Image Likes to Followers Ratio memiliki karakteristik yang tinggi, artinya semakin tinggi nilai yang dihasilkan maka semakin baik kredibilitas dari performa akun tersebut. Untuk memberikan peringkat pada masing-masing brand sepatu, peneliti memberikan angka 5 kepada brand yang mendapatkan nilai tertinggi dan angka 1 untuk brand yang mendapatkan nilai terendah. Berikut merupakan tabel urutan nilai yang dihasilkan oleh masing-masing brand sepatu.

Tabel 8. Nilai Rasio Akun Instagram 5 Brand Sepatu Lokal Terbaik di Tahun 2021

\begin{tabular}{|c|c|c|c|c|c|}
\hline RATIO & $\begin{array}{c}\text { Aero } \\
\text { Street }\end{array}$ & $\begin{array}{c}\text { Ventela } \\
\text { Shoes }\end{array}$ & $\begin{array}{c}\text { Sepatu } \\
\text { Compass }\end{array}$ & $\begin{array}{c}\text { Sage } \\
\text { Footwear }\end{array}$ & $\begin{array}{c}\text { Piero } \\
\text { Indonesia }\end{array}$ \\
\hline $\begin{array}{c}\text { Image Likes to Followers } \\
\text { Ratio }\end{array}$ & 3 & 4 & 5 & 2 & 1 \\
\hline
\end{tabular}

Sumber : Pengolah Data Excel

Dari Tabel Nilai Rasio Akun Instagram 5 Brand Sepatu Lokal Terbaik di Tahun 2021 dapat simpulkan bahwa akun Instagram Sepatu Compass mendapatkan nilai tertinggi untuk rasio Image Likes to Followers. Sedangkan akun Instagram Piero Indonesia mendapatkan nilai terendah untuk rasio ini. Jadi, pada penelitian ini Sepatu Compass memiliki kredibilitas performa yang lebih baik dibandingkan dengan brand sepatu yang lainnya. 


\section{KESIMPULAN}

Tujuan dari penelitian ini adalah mengetahui kredibilitas performa dari akun Instagram 5 Brand Sepatu Lokal Terbaik di Tahun 2021 menggunakan Image Likes to Followers Ratio. Top 5 Brand Sepatu Lokal tersebut diantaranya: Aero Street, Ventela Shoes, Sepatu Compass, Sage Footwear, dan Piero Indonesia. Dari kelima brand sepatu tersebut dapat disimpulkan bahwa:

1. Peringkat pertama diraih oleh brand Sepatu Compass dengan nilai tertinggi yaitu 0,03493456

2. Peringkat kedua diraih oleh brand Ventela Shoes dengan nilai 0,02269181

3. Peringkat ketiga diraih oleh brand Aero Street dengan nilai 0,01840500

4. Peringkat keempat diraih oleh brand Sage Footwear dengan nilai 0,00633295

5. Peringkat kelima diraih oleh brand Piero Indonesia dengan nilai terendah yaitu 0,00628796 


\section{DAFTAR PUSTAKA}

5 Brand Sepatu Lokal Terbaik di Tahun 2021. (n.d.). https://stylo.grid.id/read/142883794/5brand-sepatu-lokal-terbaik-di-tahun-2021-kualitas-terbaik-dengan-harga-terjangkau?page=all

Adrianta Surijah, E., Tesya Kirana, C., Putu Julian Dian Wahyuni, N., Chrisna Yudi, P., Komang Budi Astini, N., Studi Psikologi, P., \& Ekonomika dan Humaniora Universitas Dhyana Pura, F. (2017). MEMBEDAH INSTAGRAM: ANALISIS ISI MEDIA SOSIAL PARIWISATA BALI. Intuisi: Jurnal Psikologi Ilmiah, 9(1), 1-17. https://journal.unnes.ac.id/nju/index.php/INTUISI/article/view/9560

Cahyono, A. S. (2016). PENGARUH MEDIA SOSIAL TERHADAP PERUBAHAN SOSIAL MASYARAKAT DI INDONESIA. Jurnal PUBLICIANA, 9(1), 140-157. https://journal.unita.ac.id/index.php/publiciana/article/view/79

Inilah Negara Pengguna Instagram Terbanyak, Indonesia Urutan Berapa? | Databoks. (n.d.). $\begin{array}{llll}\text { Retrieved November 26, 2021, from } & \text { 26 }\end{array}$ https://databoks.katadata.co.id/datapublish/2021/08/03/inilah-negara-penggunainstagram-terbanyak-indonesia-urutan-berapa

Miranda, S., Evawani, P. :, Lubis, E., Jurusan, M. S., Komunikasi, I., Riau, U., Kampus, P., Widya, B., Soebrantas, J. H., 12, K., \& Pekanbaru, S. B. (2017). PENGARUH INSTAGRAM SEBAGAI MEDIA ONLINE SHOPPING FASHION TERHADAP PERILAKU KONSUMTIF MAHASISWI FAKULTAS ILMU SOSIAL DAN ILMU POLITIK UNIVERSITAS RIAU. JOM FISIP, 4(1). https://beritagar.id/artikel/sains-

Nuraeni, S. D., \& Suryawardani, B. (2017). Analisis Efektivitas Promosi Melalui Media Sosial Instagram Pada Pt. Niion Indonesia Utama Tahun 2017. EProceedings of Applied Science, $3(2)$.

https://openlibrarypublications.telkomuniversity.ac.id/index.php/appliedscience/article/v iew/3732

Prihatiningsih, W. (2017). MOTIF PENGGUNAAN MEDIA SOSIAL INSTAGRAM DI KALANGAN REMAJA. Communication, 8(1), 51-65. https://doi.org/10.36080/COMM.V8I1.651

Puspitarini, D. S., \& Nuraeni, R. (2019). PEMANFAATAN MEDIA SOSIAL SEBAGAI MEDIA PROMOSI. Jurnal Common, 3(1), 71-80. https://doi.org/10.34010/COMMON.V3I1.1950

Putu, I., \& Permana, H. (2021). Analisis Rasio Pada Instagram Untuk Penelitian Kualitatif Menggunakan Metode Ekploratif. Jurnal Sistem Informasi Dan Komputer Terapan Indonesia (JSIKTI), 3(3), 44-55. https://doi.org/10.33173/JSIKTI.109

Untari, D., \& Fajariana, D. E. (2018). Strategi Pemasaran Melalui Media Sosial Instagram (Studi Deskriptif Pada Akun @Subur_Batik). Widya Cipta: Jurnal Sekretari Dan Manajemen, 2(2), 271-278. https://doi.org/10.31294/WIDYACIPTA.V2I2.4387

Wicaksono, M. A. (M), \& Rumyeni, R. (Rumyeni). (2017). Pengaruh Media Sosial Instagram 
@Wisatadakwahokura terhadap Minat Berkunjung Followers. Jurnal Online Mahasiswa Fakultas Ilmu Sosial Dan Ilmu Politik Universitas Riau, 4(2), 1-13. https://doi.org/10.0/CSS/ALL.CSS 